\title{
Systematic Literature Review on the Use of the Internet of Things in Industrial Logistics
}

\author{
Rodolpho Izac CUENCA ${ }^{1}$, Rodrigo Lunardon TOKARS, Vitor da Cunha \\ WARNECKE, Fernando DESCHAMPS and Pablo Deivid VALLE \\ Federal University of Parana - Curitiba, Brazil
}

\begin{abstract}
In the globalized economic scenario, the ability to adapt to the flexibility of demand is crucial for the longevity of companies. In this context, industrial logistics has a key function in production flexibility. To meet this urging need, the concept of industry 4.0 brings along the use of IoT (Internet of things). Considering the importance of industrial logistics on the flexibilization of production lines, this present research presents a systematic literature review through the application of the PROKNOW-C method (Knowledge Development Process - Constructivist) aiming to understand the use of IoT (Internet of Things) in industrial logistics. The findings can be summarized by four strategical elements that should be leveraged in the decision making process by any company willing to implement IoT in industrial logistics as key factors for implementation success: clear process definition, implementation planning, people training and standardization.
\end{abstract}

Keywords: industrial logistics, Internet of Things.

\section{Introduction}

Through the capability of flexibilizing productive processes, companies are able to rapidly meet variability of customers needs (Mukherjee, 2017). This demands that processes produce different product lines on the same physical structure composed of machines and equipments (Pine II and Victor, 1993). Thus, to make sure flexibility is achieved (Mukherjee, 2017) on production lines, industrial logistics plays a major role, rapidly adapting to mix and products changes and reorganizing internal flows of material and information aiming to supply various raw materials and components needed for products or services, when they are requested, in the right quantity, in the right place and under the lowest possible cost (Cooper, Lambert, and Pagh, 1997).

Inside the context of manufacturing, there are several logistics actitivities being executed to guarantee the feeding of raw material to allow productive processes to run smoothly. (Ellinger, 2000; Hofmann and Rüsch, 2017). After the industrial revolution and following the rise of the Toyota Production System (Ito, 2016; Kidd and Monden, 1995; Liker and Morgan, 2006; Spear and Bowen, 1999), logistics became a study subject and was therefore subdivided in three main areas:

\footnotetext{
${ }^{1}$ Corresponding Author, Mail: rodolpho.cuenca@yahoo.com.br.
} 
- inbound logistics: loading and transportation of raw materials and componentes from suppliers to customers, factories and/or receiving/unloading locations;

- industrial logistics: material handling from its receiving in the unloading locations to and throught the manufacturing processes where the material will be transformed in finished goods; and

- outbound logistics: loading/collection of finisehd goods in units or batches from the manufacturers and deliveries of such to the customers location/drop points.

It is possible to find several articles that addresses the usage of Internet of Things in logistics. In order to better understand the specifics of the available technology and the applications in logistics, it is necessary to organize the papers and analyze them in the general context of use and need.

This research presents a systematic literature review through the application of the PROKNOW-C method (Ensslin et al., 2010), aiming to understand the use of the Internet of Things in industrial logistics. In particular, the literature review aims at clarifying the strategical elements and implementation factors that should be leveraged in the decision-making process by any company willing to implement IoT in the industrial logistics. Thus, Section 1 presents the selection of the bibliographic portfolio, Section 2 the bibliometric analysis of selected works, and Section 3 the content analysis of these works. Section 4 draws conclusions and makes remarks related to future works.

\section{Selection of the bibliographic portfolio}

The selection process of the article portfolio consists primarily of the selection of publications that are considered relevant in the area of knowledge to the desired research topic and fully aligned with the researcher's perception. This includes the raw bibliographic portfolio and the filtering of this raw portfolio for the selection of the articles that will compose the bibliographic portfolio to be analyzed.

\subsection{Raw bibliographic portfolio formation}

For the formation of the raw bibliographic portfolio, search terms and search period need to be defined, as well as the reference databases in which works will be searched for with these search terms.

Table 1 illustrates the search terms used, divided in two axes, one with terms related to logistics and the other with terms related to the Internet of Things. It must be highlighted that the process of establishing these search terms involved first scoping a set of terms and, through an iterative process of searching in some of the selected reference databases, refining them according to the quality of results that were obtained. 
Table 1. Search axes and keywords.

\begin{tabular}{l|l}
\hline Axle 1: Logistics & Axle 2: Internet of Things \\
\hline Logistics & Internet Of Things \\
\hline Industrial Logistics & IoT \\
\hline Logistics Sensors & Industrial IoT \\
\hline Logistics Devices & \\
\hline
\end{tabular}

After the definition of the search terms and the scoping of some scientific reference databases, three of them were selected to search for articles to compose the bibliographic portfolio, namely: Scopus, ScienceDirect and Web of Science. The searching process occurred between September $20^{\text {th }}$ and October $2^{\text {nd }}, 2019$ with a date filter for articles published between the years 2014 to 2019 as the search period. This resulted in a raw total of 914 works related to the research topic. Search results related to each one of the search terms are shown in Table 2:

Table 2. Search results by keyword combination.

\begin{tabular}{l|c} 
Keyword & Number of articles \\
\hline IoT & 33.520 \\
\hline Internet Of Things & 11.020 \\
\hline Industrial IoT & 3.571 \\
\hline Internet Of Things \& Industrial IoT & 2.542 \\
\hline Logistics Sensors & 2.265 \\
\hline Logistics \& Internet of Things & $\mathbf{9 1 4}$ \\
\hline
\end{tabular}

Finaly, an adherence test was used to check whether the keywords initially determined for searching for publications in the scientific reference databases are the ones that best align with the research theme. The Proknow-C method (Ensslin et al., 2010) suggests that a random sample of two publications be selected from the portfolio among the 914 articles that make up the raw article bank. The presented test result showed a good alignment.

\subsection{Bibliographic portfolio filtering}

After conductin the searches in the reference databases, articles need to be selected based on their affinity to the research theme (use of IoT in industrial logistics) and relevance in the research community. This filtering process includes:

a) Repeated articles filter: of the 914 articles, 172 were duplicated, resulting in 742 unique works.

b) Title filter aligned with the research theme: titles of the works were read to see if the aligned with the research theme. Only 104 papers out of the 742 unique works were aligned.

c) Abstracts filter aligned with the research theme: in this step, all 104 articles had their abstracts read in full, and only 35 were selected for being aligned with the research theme. 
d) Scientific recognition filter: the number of citation of the selected papers in Scopus was used as criteria. Only 23 articles were selected for having at least 5 citations (selected baseline) or fewer than 5 citations but published within the last 4 years in a journal with Journal Citation Ranking (JCR) above 1.5 .

e) Integral content alignment filter: in this stage, 5 articles were excluded due to misalignment with the research theme, leaving 18 articles to be used in this study. These articles are listed in Table 3.

Table 3. Articles selected to constitute the bibliographic portfolio.

\begin{tabular}{|c|c|c|c|c|c|}
\hline$\#$ & Author & Articles title & Year & JCR & Citations \\
\hline 1 & Pawel Tadejko & $\begin{array}{l}\text { Applicaton of internet of things in logistics } \\
\text { current challenges }\end{array}$ & 2015 & 0.505 & 16 \\
\hline 2 & T Stock, G Seliger & $\begin{array}{l}\text { Oppotunities of sustainable manufaturing in } \\
\text { industry } 4.0\end{array}$ & 2016 & 2.571 & 428 \\
\hline 3 & Zhang, Y Guo, Z and Liu, Y & $\begin{array}{l}\text { A framework for smart production-logistics } \\
\text { systems based on CPS and industrial IoT }\end{array}$ & 2018 & 0.174 & 27 \\
\hline 4 & $\begin{array}{l}\text { Martin Wollschalaeger, Thilo } \\
\text { Sauter and Jurgen Jasperneite }\end{array}$ & The future of industrial communication & 2017 & 0.174 & 408 \\
\hline 5 & $\begin{array}{l}\text { Christian Prasse, Andreas } \\
\text { Nettstraeter and Michael tem } \\
\text { Hompel }\end{array}$ & $\begin{array}{l}\text { How iot will change the design and operation } \\
\text { of logistics systems }\end{array}$ & 2014 & 0.174 & 21 \\
\hline 6 & Ethan Yun Yao Chen & $\begin{array}{l}\text { A new approach to integrate internet of things } \\
\text { and software as a service model for logistics } \\
\text { systems: a case study }\end{array}$ & 2014 & 0.124 & 51 \\
\hline 7 & Mengru Tu & $\begin{array}{l}\text { An exploratiry study on internet of things in } \\
\text { logistics and suppluy chain management }\end{array}$ & 2017 & 0.308 & 22 \\
\hline 8 & Chunling Sun & Internet of things leads wisdom logistics & 2018 & 1.946 & 0 \\
\hline 9 & $\begin{array}{l}\text { Judti Nagy Judit Olah, Edina } \\
\text { Erdei, Dominican Mate and } \\
\text { Jozsef Popp }\end{array}$ & $\begin{array}{l}\text { The role and impact of industry } 4.0 \text { and the } \\
\text { internet of things on the business strategy of } \\
\text { the value chain - the case of hungary }\end{array}$ & 2018 & 0.124 & 41 \\
\hline \multirow[t]{2}{*}{10} & $\begin{array}{l}\text { Sasa Aksentujevic, David Krnjak, } \\
\text { Edvard Tija }\end{array}$ & $\begin{array}{l}\text { Logistics environment awareness system } \\
\text { prototype based on modular internet of things } \\
\text { platform }\end{array}$ & 2015 & 0.458 & 254 \\
\hline & $\begin{array}{l}\text { Christian Poss, Thomar } \\
\text { Irrenhausers, Marco Pruelgmeier }\end{array}$ & $\begin{array}{l}\text { Perceptionbased intelligent materialhandling } \\
\text { in industrial logistics environment }\end{array}$ & 2019 & 3.033 & 10 \\
\hline 12 & $\begin{array}{l}\text { Diogenes Marcelo Cassiano } \\
\text { Coriguazi, Alexandre Tadeu } \\
\text { Simon, Maria Rita Pontes } \\
\text { Assumpção }\end{array}$ & $\begin{array}{l}\text { Modelo de gestão da tecnologia e do } \\
\text { conhecimento para a integração de sistemas } \\
\text { físico-cibernéticos (CPS) aos processos } \\
\text { logísticos das empresas }\end{array}$ & 2017 & 0.447 & 12 \\
\hline 13 & $\begin{array}{l}\text { Mengru Tu, Ming K Lim, Ming- } \\
\text { fang Yang }\end{array}$ & $\begin{array}{l}\text { IoT-based production logistics and supply } \\
\text { chain system- part } 1 \text { : modeling Iot-based } \\
\text { manufacturing supply chain }\end{array}$ & 2018 & 0.308 & 10 \\
\hline 14 & $\begin{array}{l}\text { Jian Liu, Shengsheg li and Yunlei } \\
\text { Zhou }\end{array}$ & $\begin{array}{l}\text { Research on the dymamic relationship } \\
\text { between industrial structure adjustment and } \\
\text { the development level of modern longistics } \\
\text { industry }\end{array}$ & 2018 & 0.558 & 51 \\
\hline 15 & Andrei Bautu, Elena Bautu & $\begin{array}{l}\text { Quality control in logistics activites through } \\
\text { internet of things technology }\end{array}$ & 2016 & 3.198 & 0 \\
\hline 16 & $\begin{array}{l}\text { Behzad Esmaeilian, Sara Behdad, } \\
\text { Bem Wang }\end{array}$ & $\begin{array}{l}\text { The evolution and future of manufacturing: a } \\
\text { review }\end{array}$ & 2016 & 2.571 & 282 \\
\hline 17 & $\begin{array}{l}\text { Lucas Santos Dalenogare, } \\
\text { Guilherm Brittes Benitez, Nestor } \\
\text { Fabian Ayala }\end{array}$ & $\begin{array}{l}\text { The expected contribution of industry } 4.0 \\
\text { techonologies for industrial performance }\end{array}$ & 2018 & 2.571 & 60 \\
\hline 18 & $\begin{array}{l}\text { Somayya Madakam R. } \\
\text { Ramaswamay, Siddharth Tripathi }\end{array}$ & Internet of things (IoT): a literature review & 2015 & 1.446 & 498 \\
\hline
\end{tabular}




\section{Bilbiometric Analysis}

With the selection of the bibliographic portolio concluded, the set of 18 selected articles was quantitatively analyzed according to the procedures presented by Azevedo et al. (2014), de Oliveira et al. (2016) and Waiczyk and Ensslin (2013). Two representations are shown here, the estimation of the degree of relevance of journals and the estimation of the scientific recognition of articles.

\subsection{Estimation of the degree of relevance of journals}

All journals in which the selected articles were published were searched for their amount of citations in the Journal Citations Report (JCR). This is shown in Figure 1. The highest scoring journal was the Journal of Manufacturing Systems, as shown in Graph 1, with 710 citations:

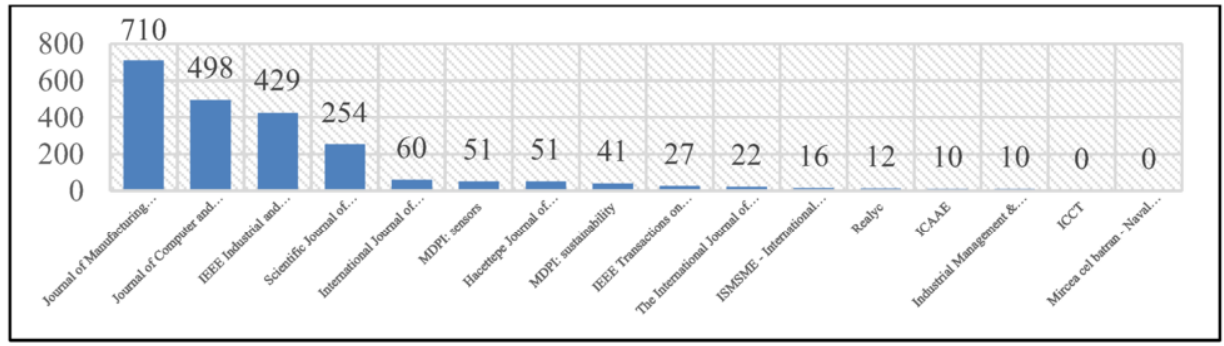

Figure 1. Index of journals in the JCR, Source: Web of Science.

\subsection{Estimatio of scientific recognition of articles}

The scientific recognition of articles consists of researching for the number of times the article was cited (Figure 2). The Scopus platform was used as a basis. The article with the most citations was: "Internet of Things (IoT) a literature review", with 498 citations. It is possible to notice that recent publications may have a lower number of citations, but still they present a high relevance to the research theme, according to what was previously discussed.

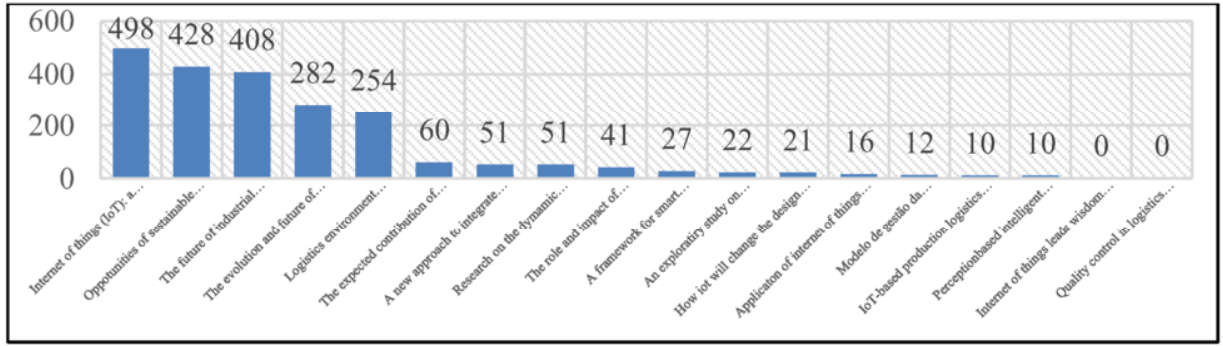

Figure 2. Number of citations received by the selected articles, Source: Scopus. 


\section{Content analysis}

The objective of this section is to provide a conceptual basis built on the knowledge acquired from reading the articles of the bibliographic portfolio.

Wollschlaeger et al. (2017) present a review of technological trends and their impact on industrial communications. The authors state that sustainability of a company's competitive advantage lies in being able to adapt quickly to the variation in demand and, in this framework, all decisions must be deployed to the level of activities, both in industrial logistics and in production. These decisions happen simultaneously all the time, leading to the principle of optimizing processes and products. Still according to the authors, there are two topics that need to be considered for the successful implementation of cyber physical systems (CPS) such as IoT-based logistic systems:

a) Intelligence modeling layers: CPS deployment must be done at the activity level to ensure that the change in orders coming from the customer permeates the initial activity, avoiding an opposite effect, which, as a consequence, can generate large inventories throughout the manufacturing structure and between processes.

b) Intelligent auto configuration of services: when implementing a CPS, it is necessary to ensure that all internal logistics services and activities are fully adaptable and reprogrammable.

Li et al. (2018) corroborates these points by stating that the evolution of the industry is only achieved with a good level of development of the communication interfaces between the manufacturing processes and the logistical systems.

In the work of Tadejko (2015) a review of the concept of IoT is made, discussing its emergence and evolution until the moment in which we live, and the changes and improvements that are perceived over the years. The author also comments that for a complete and wide diffusion of the concept and application of IoT in the most diverse segments, many years will be necessary, but the speed of expansion in recent years is impressively greater than in the last decades, all this promoted by the cheapening of sensors and connection technologies. The greatest concern presented by the author is the information security in using these devices. Among the benefits presented by the authors of using IoT in logistics are:

a) Flexibility: provide local intelligence to the decision point. According to the author, flexibility can be translated as interchangeability at the physical level (machines and equipment). This concept of interchangeability is directly linked to the concept of, when receiving an order change, having the ability and autonomy to quickly adapt, change functionality, execute new solutions or supply different products. It also points out that at the operational level, this type of application can foster changes in the level of perceived performance and the unit flow (One Piece Flow) will be allowed and promoted.

b) Robustness: the author defines robustness as intensity against interruption and operational errors. The time between failure and recovery makes it possible to measure the robustness of the process. In this way it is suggested that MTBF i (Mean time between failures) is monitored, to show the time between the detected failure and the recovery of operations.

In the view of Mayer and Schneegass (2017), the application of IoT in industrial logistics can be described as an evolution from "monitoring" the material flow to "selfcontrolling" this flow, obtained by autonomous behaviors by logistic objects within the supply chain. 
In the work of Chen et al. (2014) there are examples of improvements in logistics processes with the use of IoT, such as:

a) The replacement of labels with bar codes by RFID sensors (Radio Frequency Identification) would allow a process of receiving materials and dispatching them much faster (Want, 2006).

b) The use of reusable container with GPS (Global Positioning System) locks (Xu, 2007), highlighting the advantage of monitoring loads 24 hours a day and the benefit of reducing environmental impact, due to reuse.

c) The use of GPS locators (Aughey, 2011) allows real-time monitoring of the material flow and packaging and material inventory, both within the factory, in transit and in the possession of suppliers or customers.

\section{Conclusions}

Using the Proknow-C method (Afonso et al. 2012; L. Ensslin et al. 2010; Linhares et al. 2019; Vilela, 2014; Isasi et al., 2015) it was possible to identify a solid base of works closely aligned with the research theme.). The use of the method is highly recommended to obtain a useful knowledge base that will permeate the future works and will foster academic and industrial development.

As an overview of the use of IoT in industrial logistics, based on the knowledge acquired from the reviewed material, it can be said that the success of a digital transformation is directly related to four main factors:

a) Clear process definition: digital transformation is only recommended after the maturation of current industrial logistics processes, since investment in not well defined processes can create operational barriers that, instead of benefits, will become operational difficulties, negatively impacting the performance of logistic processes, which must be seen as services to customers (internal and external), and consequently, the results of the industry. According to Mayer and Schneegass (2017) the robustness of a cyber-physical logistics system (CPLS) is mandatory and can be defined as the insensitivity to interruptions and errors during the operation, that is, a failure-proof process.

b) Implementation: in many cases, the IoT implementation process ends up being executed without a clear definition of the steps that must be followed and the necessary prerequisites for the CPLS to function properly. This implementation flow, non-existing or incompletely defined, ends up being accomplished in different ways and methods. For this digital transformation, some references are mentioned as models (frameworks), such as Bautu and Bautu (2016), Li et al. (2018) and Pomorstvo et al. (2015). These works highlight the recommendation that the transformation be well oriented, with rigor, method and speed, combining industrial logistic processes with manufacturing management processes and cyber-physical processes (Basco et al. 2018) to be successful.

c) People training: a large part of the good results that can be obtained with the implementation of IoT in industrial logistic processes and the creation of CPLS is directly related to the training of the people involved (Costa, 2017), since eventually these new processes will be implemented and managed by people.

d) Standardization: this is an important phase of the IoT implementation process in logistics and manufacturing processes, since non-standard processes tend to create shortcuts and sub-processes that, if not mapped, can generate many 
complications and ultimately lead to the failure of digital transformation (CNI 2016; Comissió Indústria 4.0 2016; Ministero dello Sviluppo Economico 2017;

Vaidya et al., 2018).

As suggestion for future works, this work recommends that the following be addressed: the definition of a CPLS design and implementation process that is flexible and takes into account the different factors that were mentioned in this work; the definition of a CPLS architecture to be used in this process to accelerate CPLS implementation, that highlights information exchange; the mapping of standardization needs within the different logistics perspectives, for a better communication among companies in a supply chain to occur.

\section{References}

[1] A.M. Hartmann Feyh, J. Vieira de Souza, S. Rolim Ensslin, and L. Ensslin, Como Construir Conhecimento Sobre o Tema de Pesquisa? Aplicação Do Processo PROKNOW-C Na Busca de Literatura Sobre Avaliação Do Desenvolvimento Sustentável 10.5773/Rgsa.V5i2.424, Revista de Gestão Social e Ambiental, 2012.

[2] R.J. Aughey, Applications of GPS Technologies to Field Sports, International journal of sports physiology and performance, 2011, 6(3):295-310.

[3] R.C. de Azevedo, L. Ensslin, and A. Edésio Jungles, A Review of Risk Management in Construction: Opportunities for Improvement. Modern Economy, 2014, 5(4):367383.

[4] A.I. Basco, G. Beliz, D. Coatz, and P. Garnero. Industria 4.0: Fabricando el Futuro Industria 4.0: Fabricando El Futuro, 2018, http://dx.doi.org/10.18235/0001229.

[5] A. Bautu and E. Bautu, Quality Control in Logistics Activities Through Internet of Things Technology, Scientific Bulletin of Naval Academy, 2016, 19(1): 27-30.

[6] F. Chen, Z. Drezner, J.K. Ryan, and D. Simchi-Levi. 2000. "Quantifying the Bullwhip Effect in a Simple Supply Chain: The Impact of Forecasting, Lead Times, and Information, Management Science, Vol. 46, No. 3 (Mar., 2000), pp. 436-443.

[7] S.L.Chen, Y.Y. Chen, and C. Hsu, A New Approach to Integrate Internet-of-Things and Software-as-a-Service Model for Logistic Systems: A Case Study, Sensors (Switzerland), 2014. 14(4): 6144-64.

[8] CNI. Desafios Para Indústria 4.0 No Brasil, 2016, Confederação Nacional da Indústria.

[9] M.C. Cooper, D.M. Lambert, and J.D. Pagh, Supply Chain Management: More Than a New Name for Logistics, The International Journal of Logistics Management, 1997, Vol. 8, No. 1, pp. 1-14.

[10] C. da Costa, Indústria 4.0: O Futuro Da Indústria Nacional, 2017, POSGERE Número Especial Automação.

[11] A.E. Ellinger, Improving Marketing/Logistics Cross-Functional Collaboration in the Supply Chain, Industrial Marketing Management, 2000, Vol. 29, Issue 1, pp. 85-96.

[12] L. Ensslin, S.R. Ensslin, R.T. de O Lacerda, and J.E. Tasca, ProKnow-C, Knowledge Development Process-Constructivist. Processo técnico com patente de registro pendente junto ao INPI. Brasil, 2010.

[13]L. Ensslin, S. Rolim Ensslin, and H. de Moraes Pinto. Processo de Investigação e Análise Bibliométrica: Avaliação Da Qualidade Dos Serviços Bancários, Revista de Administração Contemporânea, 2013. 
[14]L. Ensslin, C. Waiczyk, L. Corrêa Chaves, and E. Rolim Ensslin, Processo Para Evidenciação Do Estado Da Arte Aplicado Ao Tema Gestão de Produção Científica. Transinformacao, 2015.

[15]L. Ensslin, C. Waiczyk, E. Rolim Ensslin, and L. Corrêa Chaves, The Process of Evidencing the State of the Art in Scientific Production Management, Transinformacao, 2015.

[16] S. Ensslin, L. Ensslin, C. Waiczyk, and L. Chaves, Modelo Para a Gestão de Produção Científica de Pesquisadores: Ilustrado Para Um Programa de PósGraduação, Pesquisa Operacional para o Desenvolvimento, 2014.

[17]B. Esmaeilian, S. Behdad, and B. Wang, The Evolution and Future of Manufacturing: A Review, Journal of Manufacturing Systems, 2016, 39: 79-100.

[18] I. Gimenez, N. Khouri, E. Morosini Frazzon, and M. Uriona, Big Data and Business Analytics in the Supply Chain: A Review of the Literature, IEEE Latin America Transactions, 2015, Vol. 13 , Issue 10, pp. 3382 - 3391.

[19]E. Hofmann and M. Rüsch, Industry 4.0 and the Current Status as Well as Future Prospects on Logistics, Computers in Industry, Vol. 89, August 2017, pp. 23-34.

[20]F. Aziz, S. Samsudin, N. Nambiar, U. Aziz, E. Li, R.Y. Zhong, Industry 4.0 in New Zealand dairy industry, Int. Journal of Agile Systems and Management, 2019, Vol.12, No.2, pp. 180 - 197.

[21] R.Y. Zhong, W. Ge, Internet of things enabled manufacturing: a review, Int. Journal of Agile Systems and Management, 2018, Vol.11 No.2, pp.126 - 154.

[22] S. Li, L.D. Xu, and S. Zhao, 5G Internet of Things: A Survey, Journal of Industrial Information Integration, 2018, Vol. 10, pp. 1-9.

[23] S. Li, Y. Zhou and J. Liu, Research on the Dynamic Relationship between Industrial Structure Adjustment and the Development Level of Modern Logistics Industry." Hacettepe Journal of Mathematics and Statistics, 2018, Vol. 48(1), pp. 1742 - 1753.

[24] J.K. Liker and J.M. Morgan, The Toyota Way in Services: The Case of Lean Product Development. Academy of Management Perspectives, 2006, 20(2), pp. 5-20.

[25] J.E. Linhares, S.L. Ribas Pessa, S.C. Bortoluzzi, and R.P. da Luz. "Work Ability and Functional Aging: A Systemic Analysis of the Literature Using Proknow-c (Knowledge Development Process - Constructivist). Ciencia e Saude Coletiva, 2019, 24(1): 53-66.

[26] S. Madakam, R. Ramaswamy, and S. Tripathi. Internet of Things (IoT): A Literature Review, Journal of Computer and Communications, 2015, 03(05): 164-73.

[27] A. Malinowski, B.M. Wilamowski, Transmission Control Protocol - TCP, In: J. D. Irwin and B.N. Wilamowski (eds.) Handbook on Industrial Electronics, CRC Press, 2010, pp. 60.1- 60.17.

[28] S. Mayer and S. Schneegass. ACM International Conference Proceeding Series IoT 2017: The Seventh International Conference on the Internet of Things, ACM, 2017.

[29] K. Mukherjee, Mass Customization, in: K. Mukherjee (eds.) Supplier Selection. An MCDA-Based Approach, Springer Nature Switzerland AG, pp. 59-66.

[30] J. Nagy et al., The Role and Impact of Industry 4.0 and the Internet of Things on the Business Strategy of the Value Chain-the Case of Hungary, Sustainability (Switzerland), 2018, 10(10), 3491.

[31]B. Pine II and B. Victor, Making Mass Customization Work, Harvard business review, 1993, Sep-Oct., pp. 108-116.

[32]F. Santos and T. Silveira, Relações Entre a Customização Em Massa e o Design de Produtos Industriais, Sistemas \& Gestão, 2011, pp. 414-430. 
[33] S. Spear and H. Bowen, Decoding the DNA of the Toyota Production System. Harvard Business Review, 1999, Sep-Oct, pp. 97-106.

[34] N.M. Stefano, and N. C. Filho, Activity-Based Costing in Services: Literature Bibliometric Review, SpringerPlus, 2013, Article number: 80.

[35] T. Stock and G. Seliger, Opportunities of Sustainable Manufacturing in Industry 4.0, Procedia CIRP, 2016, Vol. 40, pp. 536-541.

[36] S.A. Raj, K. Jayakrishna, K.E.K. Vimal, Modelling the metrics of leagile supply chain and leagility evaluation, Int. Journal of Agile Systems and Management, 2018, Vol.11 No.2, pp.179 - 202.

[37]P. Tadejko, Application of Internet of Things in Logistics - Current Challenges, Ekonomia i Zarzadzanie, 2015, 7(4): 54-64.

[38] M. Tu, Mengru. An Exploratory Study of Internet of Things (IoT) Adoption Intention in Logistics and Supply Chain Management a Mixed Research Approach, International Journal of Logistics Management, 2018, pp. 131-151.

[39] M. Tu, M.K. Lim and M.F. Yang, IoT-Based Production Logistics and Supply Chain System - Part 1 Modeling IoT-Based Manufacturing IoT Supply Chain, Industrial Management and Data Systems, 2018, 118(1): 65-95.

[40] S. Vaidya, P. Ambad and S. Bhosle, Industry 4.0 - A Glimpse, Procedia Manufacturing, 2018, Vol. 20, pp. 233-238.

[41] L. de Oliveira Vilela, Application of PROKNOW-C to Select Bibliography Portfolio and Bibliometric Analysis about Performance Evaluation of Knowledge Management, Revista Gestão Industrial Aplicação, 2014, 1(1): 200.

[42] R. Want, An Introduction to RFID Technology, IEEE Pervasive Computing, 2006, pp. 26-33.

[43] G. Xu, GPS: Theory, Algorithms and Applications, Springer, Berlin Heidelberg, 2007.

[44] L.D. Xu, W. He and S. Li, Internet of Things in Industries: A Survey, IEEE Transactions on Industrial Informatics, 2014, Vol. 10, Issue 4, pp. 2233-2243.

[45]Z. Ying, Research on Application of Modern Logistics in the Internet of Things, Applied Mechanics and Materials, 2013, 1154-56.

[46] F. Zezulka, P. Marcon, I. Vesely and O. Sajdl, Industry 4.0 - An Introduction in the Phenomenon, IFAC-PapersOnLine, Vol. 49, Issue 25, 2016, pp. 8-12.

[47] Y. Zhang, Z. Guo, J. Lv and Ying Liu. 14 IEEE Transactions on Industrial Informatics A Framework for Smart Production-Logistics Systems Based on CPS and Industrial IoT, 2018, http://eprints.gla.ac.uk/170524/http://eprints.gla.ac.uk. 